\title{
Les défis du Pacifique : questionner les concepts, repenser les conflits
}

\section{Françoise Douaire-Marsaudon}

\section{(2) OpenEdition \\ 12 Journals}

Édition électronique

URL : http://journals.openedition.org/jso/1067

DOI : $10.4000 /$ jso. 1067

ISSN : $1760-7256$

Éditeur

Société des océanistes

Édition imprimée

Date de publication : 1 décembre 2007

Pagination : 177-179

ISBN : 978-2-85430-010-9

ISSN : 0300-953x

Référence électronique

Françoise Douaire-Marsaudon, «Les défis du Pacifique : questionner les concepts, repenser les conflits », Journal de la Société des Océanistes [En ligne], 125 | Année 2007-2, mis en ligne le 01 décembre 2008, consulté le 01 mai 2019. URL : http://journals.openedition.org/jso/1067 ; DOI : $10.4000 / j s 0.1067$

\section{(c) Tous droits réservés}




\section{Les défis du Pacifique : questionner les concepts, repenser les conflits}

Ce dossier du Journal de la Société des Océanistes est issu des travaux de la sixième conférence esfo qui s'est tenue à Marseille du 6 au 8 juillet 2005 (campus Saint-Charles, université de Provence) et qui portait cet intitulé. Le thème général de la conférence Les défis du Pacifique contemporain : questionner les concepts, repenser les conflits s'est révélé particulièrement pertinent auprès d'un nombre important de chercheurs en sciences sociales, en France et en Europe, mais aussi en Amérique et dans le Pacifique. Les douze sessions de la conférence ont couvert un large éventail de préoccupations et d'intérêts scientifiques et disciplinaires, épistémologiques et théoriques. Avec près de trois cents participants, dont une proportion non négligeable d'étudiants, et plus de cent soixante exposés sans compter les discours principaux -, la conférence esfo a montré qu'elle était devenue un événement incontournable et particulièrement stimulant de la vie scientifique internationale ${ }^{1}$. De très nombreux témoignages de satisfaction ont été envoyés aux organisateurs au cours de la conférence et après sa clôture ${ }^{2}$.

Les organisateurs de la conférence ont eu l'heureuse surprise de constater la diversité croissante de l'origine géographique des participants. En effet, vingt-sept pays étaient représentés à la conférence avec, outre les membres de l'Union européenne, des États-Unis et du Canada, des chercheurs venus du Mexique, de l'Uruguay, du Chili, de Taiwan mais aussi du Pacifique: Papouasie Nouvelle-Guinée, Fidji, NouvelleCalédonie, Îles Cook, Îles Marshall et des délégations, impressionnantes en nombre, de l'Australie (trente-neuf personnes) et de la NouvelleZélande (dix-sept personnes). La venue de six chercheurs océaniens (entièrement pris en charge par la conférence, grâce à la générosité du Fonds Pacifique) a apporté une dimension particulière à la conférence et renforcé les liens de solidarité entre les Européens et les chercheurs et universitaires issus des pays du Pacifique ${ }^{3}$.

La Société des Océanistes a été étroitement associée, dès le début, aux travaux d'organisation de la $\mathrm{VI}^{\mathrm{e}}$ conférence d'esfo, en la personne d'Isabelle Leblic, qui a participé à plusieurs des réunions préparatoires de la conférence et représenté la Société au cours de son déroulement. Elle avait proposé, en fin de colloque, d'ouvrir les pages du JSO, seule revue française et européenne sur l'Océanie, pour rendre compte d'une partie des sessions et communications. Deux formules avaient alors été proposées. La première formule était de constituer un dossier général reprenant les synthèses et conclusions des différents sessions accompagnées des lectures générales ; c'est le dossier que nous présentons ici. Françoise Douaire-Marsaudon, qui était la présidente de la conférence à Marseille, a donc contacté les organisateurs de sessions pour leur demander leur texte. Tous n'ont pas répondu à la demande. Certains ont préféré choisir l'un des textes de leur session, d'autres plusieurs, certains coordonnateurs de session, publiant leurs communications par ailleurs, n'ont pas souhaité participer à ce dossier. Les textes présentés ici sont donc les suivants :

- la première lecture inaugurale en l'honneur de Raymond Firth, prononcée par M. Maurice Godelier, anthropologue, directeur de recherche à l'EHESS ;

- le discours d'ouverture de la conférence faite par M. Brij Lal, historien, professeur à la Research School of Pacific and Asian Studies (ANU, université nationale australienne) ;

1. Une liste complète des sessions et des exposés (et leurs résumés) peut être consultée sur le site web de la conférence Esfo de Marseille, à l'adresse suivante : http://www.pacific-credo.net/esfo/.

2. La VII ${ }^{\mathrm{e}}$ conférence d'Esfo se tiendra à l'université de Vérone (Italie), du 10 au 12 juillet 2008 ( $c f$. l'annonce de la conférence dans la rubrique Actualités en fin de numéro).

3. Un nombre important de participants à la conférence n'étaient pas, à leur arrivée, membres d'esfo et le sont devenus à la fin de la conférence, témoignant de l'intérêt suscité par ses travaux au sein de la communauté scientifique. 
- les présentations synthétiques de trois des sessions de la conférence : session 1 «Colonial grievances, justice and reconciliation », session 4 "Mapping Oceania Past and Present: Movements, Geographies, Identities » et session 11 "Communicating with Transculturation", un article pour les sessions 6 « Festivals and strategies of communication: cultural singularities in a dynamic network », 10 « Endangered languages - endangered cultures » et 12 « New Caledonia in Oceania : from settler colony to mining post-colony? Some contemporary social issues » et quatre articles pour la session 8 «Ownership in effect: Property, Rights, Policy and Practice in Oceania ». Cette conférence s'étant déroulée toute en anglais, cela explique que la plupart des textes présentés ici sont dans cette langue. Néanmoins, deux textes ont été traduits en français grâce à la participation financière d'Esfo que nous remercions ici.

La seconde proposition faite par le Jso était de publier quelques sessions. C'est ainsi que, suite à la conférence, Eric Venbrux et Pierre Lemonnier ont proposé le dossier du Journal de la Société des Océanistes 124 intitulé « Hertz revisité (19072007). Objets et changements dans les rituels funéraires » (session 9).

Une autre proposition de la Société, ne pouvant pas consacrer tous les numéros à venir à la publication des actes de cette conférence, était de publier certaines sessions dans sa collection Publications de la Société des Océanistes. C'est ainsi que seront publiés les actes de la session 3 «Les dynamiques de la religiosité dans le Pacifique » (en préparation) $)^{4}$.

\section{$* *$}

This special issue of the Journal de la Société des Océanistes stems from the work of the sixth Esfo conference which took place in Marseille from the $6^{\text {th }}$ to the $8^{\text {th }}$ July 2005 (Sain-Charles Campus, University of Provence) and was entitled The Challenges of the Pacific: questioning concepts, rethinking conflicts.
The following texts are presented here: the first inaugural lecture in honour of Raymond Firth given by Mr Maurice Godelier, an anthropologist and research director at the EHESS; the opening speech made by Mr Brij Lal, a historian and professor at the Research School of Pacific and Asian Studies (ANU, Australian National University); syntheses summarising three of the conference sessions ${ }^{5}$; seven articles based on papers given during different sessions.

The general theme of the conference, The Challenges of the contemporary Pacific: questioning concepts, rethinking conflicts, proved to be particularly relevant for a large number of social sciences researchers, in France and in Europe, but also in America and the Pacific. The conference's twelve sessions covered a wide range of scientific concerns and interests in many disciplines, both epistemological and theoretical. With nearly 300 participants, of whom a considerable proportion were students, and more than 160 papers - without counting the main lectures - the Esfo conference showed that it had become an essential and particularly stimulating event in international scientific life ${ }^{6}$. Many people expressed their satisfaction to the organisers both during the conference and afterwards ${ }^{7}$.

The conference organisers were pleasantly surprised to note the increasing diversity of the participants' geographical origins. In fact, 27 countries were represented at the conference with, as well as the members of the European Union, the United States and Canada, researchers coming from Mexico, Uruguay, Chile and Taiwan but also from the Pacific: Papua New Guinea, Fiji, New Caledonia, the Cook Islands, the Marshall Islands and impressively large delegations from Australia (39 people) and New Zealand (17 people). The partipation of six Oceanian researchers (totally funded by the conference thanks to the generosity of the Fonds Pacifique) added a special dimension to the

4. Une autre publication concernant les travaux de la session Langues en danger, cultures en péril (Endangered languages, endangered cultures, session 9) est en cours : «Endangered Austronesian, Papuan and Australian Aboriginal Languages», in Gunter Senft (ed.), Essays on Language Documentation, Archiving and Revitalization. Canberra, Pacific Linguistics.

5. For this issue of the Jso on the esfo conference, the chair people of each of the twelve sessions had been asked to send either a synthesis summarising all the papers or an article (two even) representing the session's work. Four syntheses were received (three accepted) as well as seven articles.

6. A complete list of the sessions and papers (and their summaries) can be consulted on the Marseille Esfo website at the following address: http://www.pacific-credo.net/esfo/

7. The $6^{\text {th }}$ Esfo conference will be held at Verona University (Italy), from the $10^{\text {th }}$ to $12^{\text {th }} \mathrm{July} 2008$ ( $c f$. Announcement of the conference and information in this issue). 
conference and reinforced bonds of solidarity between the Europeans and the researchers/ university lecturers from the Pacific ${ }^{8}$.

From the very beginning, the Société des Océanistes has been closely associated with the organisation of the sixth ESfO conference, in the person of Isabelle Leblic who attended several of the preparatory meetings for the conference and represented the Société during it. Further to the conference, a special issue (no. 124) of the Journal de la Société des Océanistes was devoted to the work of one of the conference sessions, entitled "Spiritual material: Objects and Change in Mortuary Ritual". Moreover, the Publications de la Société des Océanistes will devote a book to the proceedings of session (3) "The dynamics of Pacific religiosity" (in preparation) ${ }^{9}$.

F. D.-M.

8. A large number of conference participants were not, on arrival, members of esfo and became so at the end of the conference, bearing witness to the interest aroused by its work among the scientific community. It is not necessary to be affiliated to a European institution in order to be a member of Esfo.

9. Another publication concerning the work of the Endangered Languages, Endangered Cultures session is in preparation: "Endangered Austronesian, Papuan and Australian Aboriginal Languages", in Gunter Senft (ed.), Essays on Language Documentation, Archiving and Revitalization. Canberra, Pacific Linguistics. 
